\title{
An Evaluation of Local Mentor Support in AE E-Teacher Educational Technology Integration Online Teacher Training Course
}

\author{
Yasemin Yelbay Yılmaz, $\mathrm{PhD}$ \\ Hacettepe University, Ankara, Turkey \\ https://orcid.org/oooo-0001-8999-1565 \\ Seher Balbay, PhD \\ Middle East Technical University, Ankara, Turkey \\ iD https://orcid.org/o0oo-0001-6276-053X
}

Contact: seherb@metu.edu.tr

\begin{abstract}
This study addressed a different approach to online language teacher training programs. The researchers investigated the pros and cons of having local mentor support for an online course titled Using Technology in the English Language Classroom provided by the AE E-Teacher Program. The course was offered to preservice teachers from 24 different universities across Turkey. The study collected data through a pre- and post-online survey and individual semistructured interviews. The results revealed that while local mentoring as a supplement to the main course content contributed to teacher candidates' emotional and professional attachment to their profession by helping them relate theory to contextualized educational settings, it can still be improved by the integration of more interactive tasks that would help the attendees refer to specific practical implementation of the educational technology tools introduced in the program.
\end{abstract}

Keywords: online teacher training courses; technology integration in ELT; mentoring; local mentoring

Date Submitted February 6, 2021 | Date Published: November 3, 2021

\section{Recommended Citation}

Yılmaz, Y. Y., \& Balbay, S. (2021). An evaluation of local mentor support in AE E-Teacher Educational Technology Integration Online Teacher Training Course. Journal of Educational Research and Practice, 11(1), 279-296. https://doi.org/10.5590/JERAP.2021.11.1.20

\section{Introduction}

Teacher training in Turkey has experienced significant change over the last 3 decades, as evidenced by major revisions to the curriculum administered by the Higher Education Council of Turkey. The Higher Education Council has made several changes in the general curricula of English language teacher (ELT) undergraduate programs over the years. The 1997 curriculum reform brought about more required methodology courses adopting the curriculum to similar programs in European Union (EU) countries. The 2018 reform also emphasized the importance of practicum opportunities in addition to other changes in compulsory and elective courses on linguistic, pedagogic, and general competence (Altundiş, 2006; Kırkgöz, 2017; Nergis, 
2011). The challenge of bringing theory to life in the classroom is now supported by practice-oriented training and a wide variety of open sources available online. Teachers and teacher candidates can obtain a variety of resources for educational psychology, new approaches to pedagogy, and personal development. One of these opportunities, in the area of language teaching, is a series of online theme-specific courses offered by the U.S. Embassy throughout the world. These American English (AE) courses are available to teachers for their own professional development and teacher candidates and have proved to be popular and effective for interactive use online. One such course assists teachers with making sense of the many language teaching tools available and to use them in their lessons. A key component of the 8-week "Using Educational Technology in the English Classroom" course provided by the University of Iowa was for participants to engage in discussion with their lecturers and peers. They would then receive feedback on their discussion points, questions, and other input from the instructors and course designers. Participants needed to invest 5 to 8 hours of coursework in each weekly module. Formative assessment comprised of discussions, hands-on tasks, quizzes, and reflections.

To facilitate the delivery of the course locally in Turkey, the U.S. Embassy brought together a group of professional language teacher trainers to help promote and support its implementation nationally with input from the AE E-teachers program. The group concluded that there was a need for a local discussion forum to be incorporated with the digital platform used for delivery of the course modules. This would enable a Turkish contextualization of issues related to the course topics as they were being discussed. Contextualization of generic pedagogical content could be actuated by establishing a network of local mentors who are experienced ELTs. A grant to help facilitate the local mentoring work was obtained via the U.S. Embassy program. In this grant, the outcome of the Educational Technology Integration Online Teacher Training Course ran for 8 weeks during the spring term of 2020; however, this period coincided with the onset of the Covid-19 pandemic. This pandemic resulted in the loss of face-to-face components, including local meetings of mentors and students and an end-of-course conference that would have brought mentors and peers across the nation together. Despite the pandemic and the loss of opportunities for face-to-face consultations, participants continued their correspondence with their local mentors even after the course had been concluded. Local mentors served as a constant for the participants and continued as a point of support throughout the implementation of emergency remote teaching activities in universities in Turkey. This experience has revealed that the particular online teacher training course supported by local mentors has been a valuable asset both for designing regular education activities and especially during extraordinary times of the emergency remote teaching period that the Covid-19 pandemic introduced.

Online professional development (PD) courses provide a wealth of input for ELT professionals worldwide. These self-paced and asynchronous learning opportunities make PD readily accessible to teachers and provide opportunities for visual input and discussions led by mentors and fellows that can make the course content more interesting and engaging (Alshamrani, 2019; Dumford \& Miller, 2018). PD is now routinely integrated within preservice teacher training to assist students to gain in-depth knowledge about the profession they are entering. The Educational Technology in the English Language Classroom Course project was designed to guide and support student teachers taking an online global course. Its first aim was to employ a novel approach. This new approach aimed for a blended training model, where students could reach their local mentor throughout the course period. The mentors would be available to help them interpret course content, taking local educational setting circumstances into account. The goal of the project was to combine online, asynchronous course material designed for a global audience with online input from experienced, local mentors.

One of the principal advantages of online teacher training courses is that the participants can access the course content and communicate with their mentors and other participants in the comfort of their homes while studying a program designed by professional and experienced teacher trainers who might be residing on another continent. While teacher training courses delivered online have proven to be highly efficient in terms 
of saving time, they typically end with a significant drawback: the loss of contact between participants and instructors (Baloran, 2020; Wang et al., 2020). As a result, it is difficult to gauge the extent to which online learning has benefited a teacher as their career progresses, particularly if they miss out on securing valuable prospective collaboration opportunities with peers who have received the same training and have shared experiences of a familiar topic. The second objective of the project addressed this issue and aimed at helping build a community of participants, which was to be realized with a face-to-face meeting in the form of a mini conference upon completion of the course, to reinforce the collaboration established over several online meetings. Thus, collaboration between different universities was encouraged by course mentors.

In short, the project sought to make an online PD course available to senior and junior students studying teacher training at various universities across Turkey. This included a blended approach where global and local input was combined for the purpose of assisting students to both understand and maximize the content provided. The intervention proved to be very effective as dropout rates were relatively lower than in comparable courses that were not monitored by local mentors, and students felt more motivated to engage and continue their PD.

A call for applications was sent to universities in Turkey. Participants were then selected by a competitive screening process. Selection criteria included geographical representation, type of university (state or foundation), gender of applicants, and the quality of their letter of intention. The selection process was necessary to ensure that the course participants represented a variety of backgrounds. Senior student teachers and some junior student teachers were selected to participate. In Turkey, teacher candidate students at education faculties practice teaching in the senior year of their undergraduate programs; thus, the student teachers would have the opportunity to directly implement what they learned in the course during their teaching practice with support from their local mentors. Two local mentors were assigned to 25 students to maximize the impact of the course through input and facilitation of discussion thought relevant by them to the actual teaching context of the course participants.

The importance of having mentors familiar with local teaching circumstances and the challenges of the country-specific teaching setting cannot be denied. The local mentors who worked with the preservice teachers in this project both had more than 20 years of teaching experience at different levels, teaching different ages and in different cultural contexts. Their years of hands-on teaching experience were deployed to help synthesize theory with practice by asking them to pose the weekly questions for discussion and give feedback to participants afterwards.

\section{Literature Review}

Online teacher training is a relatively recent teacher training method, considering how far back teacher training dates. While in the 19th century there were special training programs to train teachers in Turkey, later in the 2oth century, teachers were traditionally trained in Education Faculties and via in-service training programs after graduation. ELT training was officially regarded a necessity only with the Westernization movements in Turkey dating back to the Reform Period, between 1839 and 1876 (Aksit, 2007), yet after the foundation of the Turkish Republic, formal ELT training programs in educational institutes became a requirement as English replaced French in diplomacy and business with Turkey's acceptance to the North Atlantic Treaty Organization (NATO; Büyükkantarcıoğlu, 2004). The first Education Faculty opened in 1965. In 1997, the ELT training undergraduate programs were reformed to match their EU counterparts (Kırkgöz, 2005). Today, ELT education encompasses a curriculum concentrating on language teaching methods, materials development, testing, and practice teaching (Doğan, 2020; Seferoğlu, 2004). Some ELT programs have benefited from technology integration-oriented courses in language teaching, while in some programs, there are no faculty to offer courses that would focus on the integration of technology with language teaching. 
However, with the spread of the internet, the transformation in education is reflected in teacher training programs, and the world has become an even smaller place where teacher education can reach teacher candidates from a distance. With the emergence of online teacher training programs, the training curriculum could address the special needs and interests of teacher candidates and in-service teachers. The tasks assigned have also become more flexible to meet the requirements of different educational settings. With the spread of educational learning management systems, Web 2.0 tools, and videoconferencing tools, online teacher education courses have become more interactive. It is now much easier for teacher candidates to secure opportunities for PD with these online courses. The limits of time and space traditionally associated with such education have become irrelevant, and costs are reduced or, as in the case of the present study, supported by interested parties. Although it is not yet a prevalent method of education, especially for undergraduate students in Turkey, the online mode of teacher education supported by local mentors was welcomed by the participants in the course, which reached out to 24 universities in 19 different cities in Turkey.

Online teacher training programs have long been an interest of researchers. The comparison of online and face-to-face programs address the benefits and drawbacks of each. For instance, Zweig and Stafford (2016) stated that teachers who are trained online need more training to develop themselves in multiple areas. Duncan and Bernett (2009) also investigated teacher training programs and highlighted the need for teacher candidates to obtain strategies to teach 21st-century skills. Delfino and Persico (2007) compared online and face-to-face teacher training courses and noted that there is no consensus on the content of teacher training curricula. Similarly, although with the 1997 and 2018 revisions, the undergraduate curriculum of Education Faculty programs in Turkey was standardized, the differences in the content covered still varied across different universities. While there are culture-based variations, the dissimilarity can also be rooted in pedagogical standpoints, objectives, and the resources available (Delfino \& Persico, 2007). There is a surplus of research (Adnan, 2018; Araya, 2018; Jung \& Choi, 1999) suggesting that the effectiveness of online teacher training programs depends on the instructional design quality and the integration of interactive tasks assigned. On interactiveness, Káplár-Kodácsy and Dorner (2017) suggested that reflection should be allocated time by the mentors in online programs because timing is even more important in online mentoring programs and requires meticulous planning.

In a study conducted by Rodesiler and Pace (2015) on teachers who were actively involved in online PD activities, all participants reported that professionally oriented participation online informed how they thought about teaching and shaped their practice as professional educators. They suggested that English teacher educators might require prospective teachers to participate online in various professional learning opportunities by leveraging online technologies and by producing new content (Rodesiler \& Pace, 2015). Similarly, Kabilan et al. (2011) maintained that integrating authentic online PD projects into the curriculum could allow teachers to recognize the value and importance of ICT for PD aims. They conducted an online PD project in Malaysia and concluded that ELT education programs should consider including "real" PD activities as they can challenge preservice teachers' existing beliefs, ideas, and practices in teaching the language. Their project also reaffirmed the importance of expanding the role of technology in foreign language teacher education programs. This is similar to the approach and aim of the current project. As Teräs (2016) stated, reflective, collaborative long-term $\mathrm{PD}$ that is integrated in the everyday activities of the educators is a promising approach; however, research that addresses how this can be implemented in online learning is scarce. The results of her study suggested that while collaborative online PD can be challenging, it can potentially lead to significant professional growth (Teräs, 2016). Hence, the current project aimed to acquire insights into online PD courses that appeal to the preservice teacher training context.

One of the drawbacks of online teacher training programs is the norm-referenced grading system, where identifying the norm is a challenge. To address this problem, a criterion-referenced grading system should be employed, and participants should be encouraged to set their own objectives at the beginning of the course. The online teacher training course in this study did not employ norm-referenced grading criteria because the 
local mentoring forum discussions and the interactive process of supporting and guiding the participants via several means was not led with the intention of evaluating student performance. On the contrary, it was closer to a dynamic assessment, an approach developed from Vygotsky's sociocultural theory, where the amount and type of feedback is decided on depending on the particular needs of each student, availed throughout the learning process (Poehner \& Lantolf, 2005).

Another challenge is that students participating in online training courses might find themselves in frequent need of learner support, whether it be for information and communications technology (ICT)-related issues or for contextualizing the assigned generic content. While students may misperceive online classes as easier and themselves as passive participants, some research findings have suggested that academically strong students do not prefer online classes. However, when it comes to online teacher training courses, the same does not seem to be the case (Jaggars \& Bailey, 2010; Rovai, 2003). The participants in our AE course ranked among the top students in their departments and were particularly interested in developing themselves professionally through supplementary training that was not locally available to them.

Adapting information and communication studies to teacher training goes beyond the challenges of enhancing course format; it also focuses on the possibilities online teacher training brings, such as meeting the demands of a large and diversified population. The Educational Technology Integration Online Teacher Training Course with local mentor support is intended to connect students from different cities and universities across Turkey. Undergraduate student mobility within ELT departments is rare, with the exception of the Mevlana student exchange program; hence, students are limited to the interaction they have with other students studying at their own department and have few opportunities to interact with other ELT departments countrywide (YÖK: Mevlana Programı Temel bilgiler, n.d.).

Another feature of online teacher training courses is the nuts and bolts approach they hold to be able to convey practical teaching methods and tools, which makes the teacher training curriculum comprised of fluid knowledge (Gold, 2001). Among the most easily accessible teacher training content, Gold (2001) referred to programs that help students determine the difficulty of texts, which can be used to help communicate with students or, in some cases, parents in both a professional and a time-saving, practical way to help give feedback orally or in written format or to help students collaborate among themselves or with the teacher, adding some creativity and fun in class. While the idea of reaching out to masses of teacher candidates is appealing and time-, energy-, and cost-effective, to convey content that is generic enough to address different needs in varying teaching settings lacks the context-specific and culture-specific focus. That is why the present project is intended to supplement the missing local mentoring aspect.

Beyond the overview of the contribution of online teacher training courses, it is also relevant to analyze the expectations from mentors in teacher training. In the simplest form, a mentor is defined as a "wise and trusted teacher" (Aslan \& Öcal, 2012). Daresh (2003) also emphasized that it is wisdom not knowledge that a mentor aims at passing on to the mentees. Although there are many studies on mentoring preservice teachers, providing online mentoring is a less researched area. Pena and Almaguer (2007) found that the use of webbased technologies appears to enhance the student teaching experience by allowing the supervisor to provide information and support $24 / 7$ and by providing a medium where students can commiserate, share successes, and exchange information. Similar findings were obtained in the current study. With the outbreak of the Covid-19 pandemic, online PD opportunities and online mentoring have become more crucial than ever. Research is now focused on this area of PD to cater to the needs of preservice teachers. Online mentoring has become particularly important. In a significant study on online mentoring in the Turkish context, Ersin et al. (2020) directly addressed the pandemic and designed an alternative practice to meet the practicum needs of undergraduate ELT students who were to complete their practicum before the outbreak. They coined their project "e-practicum" and the mentors involved "e-mentors." Virtual classrooms were created on a digital platform, and students performed six microteaching sessions. After each session, students received feedback 
and e-mentoring and reflected on their experience. The findings revealed that participants found the epracticum useful because it helped them overcome online teaching fears (Ersin et al., 2020). In a similar study, Briscoe (2019) explored the effectiveness of virtual mentoring partnership between practicing teachers and preservice teachers. She conducted the research with two separate groups of 77 students over a 3-month course in 2 consecutive years. She found that preservice teachers found the process overwhelmingly positive. After engaging in a guided virtual mentorship with an experienced teacher, they felt more prepared, more confident, and more supported. Briscoe explained that the response from preservice teacher participants provided evidence and confirmed a sense of improved educational preparedness for teaching by engaging in a guided virtual mentorship partnership with an experienced teacher. Although these studies shed light on what the preservice teachers think about online mentoring, more research needs to be conducted to be able to contribute to online mentoring applications. This project is significant in that it provides additional data about the Turkish context.

In preparing the evaluation of the project, the method chosen depended on the fact that the phenomenon is not distinguishable from its context. Hence, a case study methodology was followed to identify problems and achievements of local mentor support for the online language teacher training course and improving future online teacher training courses with the data obtained. Accordingly, the following research questions were prepared:

1. What effects did the preservice teachers report from receiving the online teacher training course?

2. What is the contribution of the local mentors on the effectiveness of the online teacher training course?

\section{Method}

Participants in the $\mathrm{AE}$ online teacher training course were given an online survey about their expectations and experience at the beginning of the training. They were given another online survey reflecting on their experience at the end of the training session, which lasted 8 weeks. Fifteen participants responded to both surveys. Six participants were also interviewed to triangulate the data obtained from the pre- and postsurveys. The survey questions were analyzed through descriptive statistics, and we analyzed the interviews via thematic coding. Sample interviews were also analyzed by two other researchers who were very familiar with the particular course offered and the responsibilities of the mentors. The recurring codes were categorized under common themes according to Saldaña's (2021) coding cycles. In the first cycle, the transcriptions were coded by rather generic codes, such as emotional, technical, and professional contribution references. The second cycle concentrated on synthesizing the previous codes according to negative and positive references and the issues that had room for improvement.

\section{Participants}

The project was intended for junior and senior students who were enrolled in ELT departments throughout Turkey. To reach out to as many students from various backgrounds as possible, the call for the project was circulated both by the U.S. Embassy in Ankara and via the networks of the project mentors and the project coordinator in September and October of 2019. Eighty-nine students from 19 cities in Turkey applied for the program, and the mentor team selected 25 students against predefined criteria, such as geographical representation, state versus foundation university, junior and senior student balance, and gender balance. The project was advertised, and a call was sent to university ELT departments in Turkey. Interested students sent in an application form that collected descriptive data and a statement of purpose inquiring about why they wanted to participate in the course, in what ways they thought they would benefit from the course, and how 
they were planning to cascade knowledge obtained from the course. The application process was highly competitive, and candidates were selected based on the preset criteria.

The course was only offered to junior and senior students to ensure they could apply and implement what they learned in the course during their internship at schools in Turkey. Senior students comprised $72 \%$ of the group while $28 \%$ of the participants were in their junior year in their departments. The gender ratio was normal, with $64 \%$ female and $36 \%$ male students. Ninety-six percent of the students were enrolled in state universities. Location and university type (state vs. foundation universities) were part of the criteria, and priority was given to students from remote locations in Turkey as well as students who were enrolled in state universities.

\section{Intervention}

The eight course modules were delivered over a period of 8 weeks, starting in January 2020. Canvas was used as the online course provider platform. Participants followed the course modules asynchronously at their own pace, but there were set deadlines for the tasks within each module. After completion of each module, and during the course module, formative assessment tasks were employed to assess each participant's progress. Mentors could also monitor each participant's time spent on the course modules as well as the grades they received from each assessment tool (such as performance in group discussions, end of course quizzes, and performance tasks).

Participants were monitored by two support groups. One group consisted of instructors who designed the course. The instructor group provided feedback and monitored general participation and engagement of the participants. The local mentor group consisted of two experienced mentors who lived and worked in Turkey. The task of the local mentors was to monitor participants' progress and provide feedback on how they could implement what they have learned in the course in a Turkish context. The local mentor group set up a separate discussion forum within the Canvas platform so that participants could further their discussions with their local context in focus. The local mentors also started a Whatsapp group for instant question-answer and feedback needs. The Whatsapp group was also used by the mentors to foster bonding among the participants as an interactive group of learners. In short, both the instructor group and the local group provided different types of support and assumed different roles in the course.

The local mentors did not participate in the course module discussions so as not to interfere with the instructors' comments. They created a different subgroup for discussions with the participants where they regularly posted questions related to the materials they were studying. The questions mainly aimed at facilitating reflection for the participants about what they had been learning and ways of implementing that knowledge into the English teaching context in Turkey. The mentors asked Socratic questions where they encouraged participants to interact with each other and exchange ideas (see Balbay, 2019). The questions did not have fixed right or wrong answers; rather, they were questions triggering critical thinking and conceptualization of discrete content knowledge under stances, perspectives, attitudes towards the language teaching profession, and its hands-on implications. There were also reflections requiring questions expecting students to identify differences in their own language learning experience and the new trends introduced in the course content. The participants responded to other participants' answers on a forum-like interface on the Canvas platform, and the mentors responded to the answers guiding and providing support where necessary. They occasionally prompted participants with a discussion question that could be discussed via Whatsapp as well. Mentors also answered specific questions that were directed by participants and shared relevant anecdotes from their own teaching experience. During the correspondence through the Whatsapp group, there were messages that were simply aimed at socializing; this process proved to be effective to break the ice and build a learning community. All in all, the local mentors provided support where necessary as mentor, 
facilitator, and contact person if participants had problems with the course content or the tasks assigned throughout the course.

\section{Data Collection and Analysis}

We conducted a pretest and posttest and semistructured interviews to collect data from the participants. The pretest collected descriptive data and participants' expectations about the course content as well as participants' understanding about what mentoring is. The posttest mainly explored participants' views on the effectiveness of the course and the mentoring process. Both the pretest and the posttest were self-developed online surveys. However, they were piloted first on two students who experienced taking an online language teacher training course and were edited and revised considering the feedback received from two local mentors who supported another general audience language teacher training course. Only minor changes in wording were made to clarify the intended meaning after receiving the feedback. The Likert-type questions that both the pretest and the posttest contained can be seen in Table 1. The results were then analyzed, and conclusions were drawn. The semistructured interview questions used to activate the participants' schemata are below:

- How do you think the online technology integration in the ELT course helped you as a preservice teacher?

- What do you think the local mentors added to the main course process?

- How have you benefited from the local mentor support throughout the course?

- Has your idea about becoming an English teacher changed? Why?

- Has your idea about what type of school you wanted to work in changed? Why?

- How proficient do you think you are in English teaching? Has the course contributed to this opinion?

- Please evaluate and compare face-to-face courses that you attended in your department and this online course in terms of efficiency, mentor support, and relevance to your teaching context.

- The participant retention rate in this course was exceptionally high (most of the participant's finished the course). What motivated you most to continue?

\section{Results}

The course was only offered to junior and senior students to make sure that they could apply and implement what they learned in the course during their internship at schools in Turkey. Senior students comprised $72 \%$ of the group while $28 \%$ of the participants were in their junior year in their departments. The gender ratio was normal, with $64 \%$ female and $36 \%$ male students. Ninety-six percent of the students were enrolled in state universities. Location and university type (state vs. foundation universities) were part of the criteria, and priority was given to students from remote locations in Turkey and students who were enrolled in state universities.

In the pretest, data were also collected about their motivation for becoming an English teacher by asking if the ELT department was among their first five choices in the university exam. For most of the participants, their department was among the first five choices. Answers to another question about whether participants wanted to become an English teacher after graduation revealed that 9 out of 10 of them did. This cohort of students was a highly motivated group who had clear goals about their future profession.

In the surveys, there were questions related to participants' ideas and attitudes towards PD in general, online PD, and technology use in the ELT classroom. A 5-point Likert scale was used in the pre and posttests. The mean scores and $S D$ values of the items in the pre and posttests are given in Table 1. 
Yılmaz \& Balbay, 2021

Table 1. Pre and Posttest Scores of Participants' Opinions on Relevant Concepts in the Course

\begin{tabular}{|c|c|c|c|c|}
\hline Likert-type items & $\begin{array}{l}\text { Pretest } \\
M\end{array}$ & $\begin{array}{l}\text { Pretest } \\
S D\end{array}$ & $\begin{array}{l}\text { Posttest } \\
M\end{array}$ & $\begin{array}{l}\text { Posttest } \\
S D\end{array}$ \\
\hline 1. I am proficient enough to teach English. & 4 & 0.8 & 4.3 & 0.5 \\
\hline 2. Teaching is a skill that can be developed. & 4.5 & 0.8 & 4.8 & 0.3 \\
\hline $\begin{array}{l}\text { 3. Face-to-face teacher development courses have more } \\
\text { advantages than online courses. }\end{array}$ & $3 \cdot 7$ & 1.1 & 4 & 0.6 \\
\hline $\begin{array}{l}\text { 4. Online teacher development courses can be as } \\
\text { effective as face-to-face courses. }\end{array}$ & 4.2 & 0.6 & 4.3 & 0.7 \\
\hline $\begin{array}{l}\text { 5. I feel ready to integrate technology in my lessons in } \\
\text { the future. }\end{array}$ & 4.4 & 0.6 & 4.4 & 0.6 \\
\hline
\end{tabular}

As seen in Table 1, the averages leaned towards strongly agree where 5 was strongly agree and 1 was strongly disagree, except for Question 3, where the standard deviation was low. Questions 1 and 2 aimed at collecting data about the participants' ideas about PD in general. In Question 1, the pretest aimed at collecting data on the current ideas of the participants about their own readiness to teach English by rating themselves on the statement, "I am proficient enough to teach English" $(M=4, S D=0.8)$; the same question was repeated after the 8-week course modules were completed $(M=4.3, S D=0.5)$. Question 2 asked whether participants thought that the ability to teach could be learned and further developed with the following statement: "Teaching is a skill that can be developed." The pretest showed a high tendency towards strongly agree ( $M=$ $4.5, S D=0.8)$ and a slight change towards strongly agree in the posttest $(M=4.8, S D=03)$.

Questions 3 and 4 asked about the effectiveness of online PD courses compared to face-to-face PD courses. Participants tended to agree less with the item "Face-to-face teacher development courses have more advantages than online courses" ( $M=3.7, S D=1.1)$, and the $S D 1.1$ was the highest among the items. The posttest average for this item was $M=4$ and $S D=0.6$. Also, for Question 4, averages of the pre and posttest did not reveal a large change, with the pretest being $M=4.2, S D=0.6$ and the posttest $M=4.3$ and $S D=0.7$.

The last question aimed to determine the readiness level of participants to integrate technology in their future teaching. The pre and posttest did not show any difference for the question "I feel ready to integrate technology in my lessons in the future," with both the pre and posttest scores being $M=4.4$ and $S D=0.6$.

The goal of this study was to explore the impact of the local mentoring process on the teacher candidates who were enrolled in technology integration in an ELT course. As mentioned above, what differs in in this study is that experienced teachers in the Turkish context constantly monitored, gave discussion tasks and feedback, and motivated the teacher candidates to take the online teacher training course through reflective teacher training practices. They were engaged in a personal relationship with the candidates and attended to their needs throughout the course, especially by helping them relate the course content to the possible teaching contexts they were expected to teach in when they graduated from their undergraduate programs. In Table 2, the participants' perceptions of the contribution of local mentors to their online teacher training course can be observed. 
Yılmaz \& Balbay, 2021

Table 2. Participants' Opinions on the Local Mentoring Process

\begin{tabular}{|c|c|c|}
\hline Likert-type items & $M$ & $S D$ \\
\hline Effective mentoring can only be done face to face. & 1.9 & 0.9 \\
\hline $\begin{array}{l}\text { This distance education process with local mentoring developed my ability to } \\
\text { apply theory into practice }\end{array}$ & $4 \cdot 3$ & 0.6 \\
\hline $\begin{array}{l}\text { The local group discussions were effective in elaborating on the topics in the } \\
\text { modules. }\end{array}$ & $4 \cdot 3$ & 0.6 \\
\hline $\begin{array}{l}\text { The local group discussions developed my ability to think critically about my } \\
\text { profession. }\end{array}$ & 4.2 & 0.7 \\
\hline The local discussion opportunities for interactive learning were adequate. & 4.5 & 0.6 \\
\hline $\begin{array}{l}\text { The local discussions helped me to gain a clearer understanding of the possible } \\
\text { local teaching contexts in my country. }\end{array}$ & 4.4 & 0.7 \\
\hline $\begin{array}{l}\text { The local group discussions helped me in improving my performance in the } \\
\text { course. }\end{array}$ & 4. & 0.7 \\
\hline Did you go back and read the local group discussions? & 2.9 & 1.7 \\
\hline My mentors were helpful. & 4.7 & o \\
\hline My mentors were accessible and available when I needed them. & 4.7 & o \\
\hline I would like to stay in contact with my mentors in the long term. & 4.5 & 0.6 \\
\hline My mentors provided constructive feedback. & 4.5 & 0.4 \\
\hline My mentors illustrated good mentoring skills. & 4.5 & 0.4 \\
\hline I would like to do another course with the same mentors. & 4.5 & 0.6 \\
\hline My mentors assisted me in improving my performance in the course. & 4.4 & 0.6 \\
\hline My mentors demonstrated interest/concern towards me. & 4.4 & 0.6 \\
\hline My mentors' behavior and attitude generally is an example of professionalism. & 4.6 & 0.3 \\
\hline I learned at least one lesson about the teaching profession from my mentor. & 4.6 & 0.3 \\
\hline
\end{tabular}

To answer the second research question evaluating the effectiveness of the local mentors on the teacher candidates during the course period, two different data collection methods were used: the online survey and the interviews. Likert-scale questions in the online survey were analyzed using descriptive statistics. Openended questions were analyzed through thematic content analysis. Thematic analysis was described by Braun and Clarke (2006) as "a flexible and useful research tool, which can potentially provide a rich and detailed, yet complex account of data" (p. 5). While collecting and analyzing data, the 6 stage qualitative data collection and thematic analysis proposed by Peel (2020) was employed: identifying the issue, collecting the data, preparing and engaging with the data, analyzing the data thematically, interpreting the data analysis, and composing the research findings and generalizations. Following Peel, at the thematic analysis stage, the codes 
were reduced systematically to code categories and themes. They were generated inductively from the patterns in the data that were informed by sourcing existing knowledge from the literature. We began with a short list of categories (lean coding), as suggested in Creswell (2013), and then expanded the categories by reviewing and rereviewing the database. At the last stage, findings were contextualized, and the research questions were addressed through the interpretations.

In Question 19, the participants were asked to define who a mentor is. The mentor characteristics they suggested in their answers were about personality rather than academic features, position, or title. While some participants provided the exact names of the local mentors of the course, most of them defined the mentor concept as someone who is experienced in teaching and who supports, guides, and inspires them, provides feedback, and supervises them. Only one participant stated that "a mentor is someone who knows how to use tools of teaching." Other participants did not refer to the profession of teaching and emphasized the leadership, expertise, and organizational skills of mentors.

The 2oth question was significant because it focused on the roles of the mentors in teacher training. In teacher training, participants' answers were very similar to the definition of a mentor in general, which was asked in the previous question. The participants replied to the question, focusing on the guiding, leading, monitoring, and helping skills of mentors in the teacher training process.

In the question that asked the participants three adjectives to define mentors, the answers were clustered under being approachable (accessible, open, positive, understanding, friendly, kind), being supportive (helpful, advisor, supportive, motivating, encouraging, conductor), being inspiring (leading to new ideas, passionate), and being competent (knowledgeable, expert, professional, skillful, wise, innovative, creative).

In the Likert-scale questions, the standard deviation was very low, and the averages had a leniency leaned towards strongly agree where 5 was strongly agree and 1 was strongly disagree. The findings showed that the participants did not think that "effective mentoring can only be done through face-to-face content" $(M=$ 2.2, $S D=0.9$ ). Most of the participants strongly agreed with the following statement: "This distance education process supported by local mentors developed my ability to apply theory into practice" $(M=4.6, S D$ $=0.6$ ). The participants stated that they took part in the local group discussions led by the local mentors on topics parallel to the online teacher training course content $(M=4.4, S D=0.6)$. Almost all of the participants strongly agreed with the following statement: "The local group discussions were effective in elaborating the topics in the modules" ( $M=4.6, S D=0.6)$. Likewise, almost all of the participants strongly agreed with the following statement: "The local group discussions developed my ability to think critically about my profession" $(M=4.5, S D=0.7)$. The participants thought that the local discussion opportunities for interactive learning were adequate $(M=4.8, S D=0.5)$. The participants reported that the local discussions helped them to gain a clearer understanding of the possible local teaching contexts in their country $(M=4.7$, $S D=0.7)$ and that the local group discussions helped them in improving their performance in the course $(M=$ 4.6, $S D=0.7)$. Only some of the participants went back to the local group discussions to reread them $(M=$ $3.2, S D=1.7$ ), which was a flaw in the design of the local mentor activities because the teacher candidates did not have a reason in the task design to go back and read the forum flow of the discussions after they posted their own reflections and read the mentor's comments. Hence, the flow was not dialectic but was in a monologue with a response from the mentors. This is a major feature that hindered frequent coherent communication on the online platform, which can shed light on future online teacher training platforms supported by local mentors. Most of the participants, both in the surveys and in the interviews, revealed that they had serious time constraints meeting the deadlines, which prevented them from going back to the discussions with the local mentors to further the written dialogue in the forums. All of the participants strongly agreed that the mentors were helpful throughout the course without any exceptions, and they all expressed a will to continue to keep in touch with their mentors even after the course ended. Likewise, almost all participants strongly agreed that their mentors' feedback was constructive $(M=4.5, S D=0.3)$ and that 
they would like to take another course with the same mentors. The participants thought that the local mentors helped them improve their performance in the course to a large extent $(M=4.4, S D=0.5)$ and that their mentors demonstrated genuine interest in them $(M=4.4, S D=0.5)$. Moreover, the local mentors' behavior and attitude were examples of professionalism $(M=4.6, S D=0.2)$.

The participants reported that the local mentors were helpful in various ways. While some of the participant teacher candidates stated that they were influenced by a perspective towards life by their mentors, they were motivated to be disciplined and to have a positive attitude towards challenges. Some of them referred to more specific skills, such as an online educational tool, a teaching method, motivation-related strategies to employ with their own students, or a new perspective to look at native-like accents. Some of the mottos included teachings such as believing in yourself. One of the teacher candidates noted that she learned how to provide constructive feedback, and another participant wrote that receiving feedback constantly and adjusting the content according to the audience was one of the points she learned from the local mentors. The findings on the positive perception of the mentors in this study are parallel to the findings of Hudson and Nguyen (2009). Hudson and Nguyen stated that "preservice teachers have particular mentoring needs and requirements that may assist their development as [English as a foreign language] EFL teachers." The features of mentoring teachers in the present study were mainly as follows: enthusiastic, helpful, and knowledgeable with communicative competence.

Only participants who completed the posttest were invited to take part in the online interview, and six out of the 15 participants who completed the posttest volunteered to take part in this interview. The interview followed a semistructured format where participants could elaborate more on the items asked in the posttest. Five questions from the posttest that were most talked about and added more insight to the posttest were thematically analyzed.

Participants commented on their goals about becoming an English teacher, which was a question in the descriptive data questions of the survey. Three participants wanted to become an English teacher, and one participant wanted to become a researcher in ELT. None of the participants changed their idea through the course, however; they stated how the course validated their decision and in what ways it motivated them. One participant stated that she was afraid of using technology because she believed that it interfered with her role as a teacher, but by the end of the course, she noticed that she could easily integrate technology into her classrooms and vary her activities using multiple digital resources. Participants stated that this course motivated them more to become an English teacher. Participant 3 stated, "My idea about becoming an English teacher hasn't changed but through this course, I want to be a teacher even more because this online course helped me realize the important elements of being an English teacher."

When asked about the ways the course helped them to improve, participants said that this course helped them receive new information to work with and new resources to discover. They also stated that the course has given them a new area to discover within their field. They felt more confident about teaching different age and level groups in the future. One participant suggested that "it is clearer for me now, how to differentiate my teaching skills according to school type, students' ages and levels." They also expressed that their ideas about teaching different groups changed. Participant 5 said, "However, as I proceeded, I learned how to teach them English effectively using technology.”

In response to how proficient they thought they were to teach English, the course added to their sense of proficiency by providing input on the digital tools that they could effectively use to efficiently to maximize language learning. Some of the participants explicitly stated that their teaching skills had improved in the course. Students expressed that they already felt proficient before the course but that the course added to their skills. Participant 1 emphasized that, "The course showed me different practical perspectives to use technology and it contributed to my perception of being proficient and improvable." 
The participants also responded to questions comparing online PD courses with face-to-face PD courses. The participants found that both formats were relevant and that the online course was as effective as the face-toface courses. Participant 4 shared, "I could make a direct connection between this course and our teaching practice in a real classroom." As for mentor support, participants stated that online mentor support was as effective as face-to-face mentor support as they could frequently communicate with their mentors. One participant stated that she needed the face-to-face aspect to internalize what the mentor said. Another participant stated that she preferred the online PD course because reaching her lecturer at her departments was difficult. Participants mentioned the efficiency of the Whatsapp group founded by the mentors and that they felt cared for. Participant 2 said, "This dedication and perseverance attracted my attention since it is hard to meet such caring professionals in every online course."

Another question explored motivation and what kept them continuing their online study in the course. Results revealed that the content itself and the prospective skills they would gain were the biggest motivational factors. This was followed by being able to earn a certificate as proof of their accomplishment. Meeting people from different parts of Turkey, the welcoming and supportive mentoring, and that the project was encouraging participants to implement what they learned in the course were also mentioned as important motivation factors. Participant 6 said, "Besides, the welcoming and supportive treatments of my mentors supported me very much, so I did not drop the course even though I had to deal with my thesis, practicum studies, etc."

\section{Discussion}

The results of the first set of the pre and posttest questions showed very slight changes, if any, in the attitude and ideas of participants about PD, online PD, and using technology in the classroom. This is an expected result, as this cohort of participants was a highly motivated group of undergraduate students who competed for this opportunity based on high-set criteria. Hence, the level of awareness of the concepts asked about in the survey was high. Another factor that explains the high level of awareness of the participants can be attributed to the fact that this group consisted of students for whom the ELT departments were among their first five choices in the university exam. For $84 \%$ of the participants, their department was among the first five choices. Furthermore, $92 \%$ of the participants wanted to become an English teacher upon graduation. In short, this cohort of students was a highly motivated group who had clear goals about their future profession and had considerable readiness when they started the course.

The course was offered to junior (28\%) and senior students (72\%) to make sure that they could apply and implement what they have learned in the course during their internship in schools in Turkey. This also ensured that the participants had received considerable input about teaching, which showed in the answers they gave at the pre and posttest. The participants already thought they were proficient to teach English (pretest, $M=4, S D=0.8$ ) and that teaching is a skill that can be developed (pretest, $M=4.5, S D=0.8$ ). Thus, their readiness level at the beginning of the course was high. The posttest for the items above revealed even more change towards strongly agree, which shows that the AE course validated their ideas and attitudes about themselves as future teachers and PD in general (posttest, $M=4.3, S D=0.5$ and $M=4.8, S D=0.3$ respectively).

The other set of questions in the survey was about PD and what the participants thought about PD in general and in an online form. The lowest score of the pretest items was about the question that asked if face-to-face teacher development courses have more advantages than online courses. The average of 3.7 in the pretest showed that, although undecided, the group leaned towards agreeing with the item; in other words, the participants tended to believe that face-to-face teacher development courses have more advantages than online courses. The $S D$ for this item was 1.1, which was the highest among the items; hence, it can be 
concluded that the group was of different opinions about this question, compared to the other items. The posttest showed that the group agreed with the statement $(M=4)$, and the group had similar ideas compared to the pretest $(S D=0.6)$. That being said, the change in the mean is not enough to conclude that the participants prefer to receive mentoring face to face in the future. Item 4 was about the efficiency of online PD courses. Comparing the means, we found slight changes; however, these were not enough to make conclusions about what the participants thought about the item. As mentioned above, this group was already a group with high awareness on themes like PD and using technology in the classroom. Therefore, considering the high pretest scores, dramatic changes were not expected from the very start of the project.

The last item was about technology use, and there was no change between the pre and posttest average points. It can be argued that the participants already had a high awareness about using technology in the classroom $(M=4.4, S D=0.6)$, and this did not change during the course. Although by analyzing quantitative data, it can be concluded that the course modules had no effect on the participants in terms of technology use, qualitative data collected from group discussions showed a great deal of benefit and enthusiasm on the part of the participants.

Participants who took part in the interviews elaborated on what they stated in the pre and posttest and said that the course motivated them to use technology more in their classes and served as confirmation for their desire to become an English teacher. They stated that the online PD course was as effective as the face-to-face courses and that the online courses proved to be very effective. This is supported by Rodesiler and Pace (2015) who suggested that online PD may also offer a lifeline to novice teachers who face issues of isolation, a need for a supportive professional community, and a paucity of opportunities for face-to-face PD focused on literacy and the English language arts. Participants stated that the presence of mentors in the course motivated them and improved their performance. Analysis of the themes revealed that the most appreciated qualities/roles of the mentors as stated by the participants during the interviews were being available for them when they needed support, receiving answers quickly as in a face-to-face course, and personal qualities like being welcoming, supportive, warm, positive, and approachable. Being available appeared as the most frequent category not only in an online course but also in face-to-face settings. This is best reflected in one of the comments of Participant 6: "However, in my department, I sometimes have difficulty in counselling my instructors even though I meet them face-to-face."

\section{Conclusion}

This study revealed that although online courses can be efficient in themselves, mentor support made the course experience more worthwhile for participants, motivated them to continue and complete the courses, and added to the value and impact potential of the course content in general. It is clear that mentors may assume many different roles in online courses, ranging from being a consultant to a person who builds a closer personal relationship, which in return can have a positive effect on the course performance. Although we conclude that more research needs to be conducted on a blended approach similar to the one employed in this study to research its effect and long-term impact, we maintain that a blended approach adds value to online PD in general.

This becomes particularly critical in global online courses where the course is designed for a generic audience and designing the content in a culture or context-specific manner might be a challenge for the course designers. This can be overcome by inserting into the course eco-system local mentors who can build rapport more easily, provide contextualized input that is more relevant to the participants' professional environment, and establish a mentoring environment that motivates participants to continue the course and cascade knowledge, hence creating wider impact. 
Although this study was based on a grounded approach, and we did not have any theses in mind, we expected that the mentoring would be particularly significant in cultural aspects of the course and providing local input regarding the content. However, the findings suggested that aspects such as motivation and emotional support were equally important in the process. These aspects were included in a simplistic manner through a free online digital classroom tool and a free messaging service that allows text, photo, video, and sound sharing. With the help of these tools, the local mentors could easily achieve the above-mentioned effects. Adding a local mentoring component to an online course seems to fulfill more goals than foreseen, depending on the needs of the participants. To conclude, we maintain that a blended approach with online and local mentoring aspects in an online course is effective, not only in terms of performance and impact but also motivation and much sought genuine interaction. 


\section{References}

Adnan, Z. (2018). Upgrading EFL teachers' quality through an online mentoring system, an innovative inservice training model: The case of Indonesia. Jurnal Humaniora, 30(2), 158-166. https://doi.org/10.22146/jh.34844

Aksit, N. (2007). Educational reform in Turkey. International Journal of Educational Development, 27(2), 129-127. https://doi.org/10.1016/j.ijedudev.2006.07.011

Alshamrani, M. (2019). An investigation of the advantages and disadvantages of online education [Unpublished doctoral dissertation]. Auckland University of Technology.

Altundiş, E. (2006). İngilizce öğretmenlerinin eğitimsel kökenleri ve dil öğretiminde karşılaştıkları sorunlar (Kayseri ili örneği) (Unpublished Master's thesis). Erciyes University.

Araya, R. (2018). Teacher training, mentoring or performance support systems. Advances in Intelligent Systems and Computing (pp. 306-315). https://doi.org/10.1007/978-3-319-93882-0_30

Aslan, B., \& Öcal, S. D. (2012). A case study on mentoring in teacher development programs. Journal of Education, 2, 31-48.

Balbay, S. (2019). Enhancing critical awareness through Socratic pedagogy. Eurasian Journal of Applied Linguistics, 5(3), 515-536. https://doi.org/10.32601/ejal.651348

Baloran, E. T. (2020). Knowledge, attitudes, anxiety, and coping strategies of students during Covid-19 pandemic. Journal of Loss and Trauma, 25(8), 635-642. https://doi.org/10.1080/15325024.2020.1769300

Braun, V., \& Clarke, V. (2006). Using thematic analysis in psychology. Qualitative Research in Psychology, 3(2), 77-101. http://doi.org/10.1191/1478088706qpo63oa

Briscoe, P. (2019). Virtual mentor partnerships between practising and preservice teachers: Helping to enhance professional growth and well-being. International Journal of Mentoring and Coaching in Education, 8(4), 235-254. https://doi.org/10.1108/IJMCE-02-2019-0023

Büyükkantarcığlu, N. (2004). A sociolinguistic analysis of the present dimension of English as a foreign language in Turkey. International Journal of the Sociology of Language, 165, 33-58.

https://doi.org/10.1515/ijsl.2004.006

Creswell, J. W. (2013). Qualitative inquiry \& research design: Choosing among five approaches. SAGE Publications.

Daresh, J. C. (2003). Teachers mentoring teachers: A practical approach to helping new and experienced staff. Corwin Press.

Delfino, M., \& Persico, D. (2007). Online or face-to-face? Experimenting with different techniques in teacher training. Journal of Computer Assisted Learning, 23(5), 351-365. https://doi.org/10.1111/j.13652729.2007.00220.x

Doğan, C. (2020, December 19). Reflections from the three phases: The pre, while and post (Keynote speech presenter). Dare, Adapt and Transform, Being an ELT teacher in the 21st Century Online Zoom Conference.

Dumford, A. D., \& Miller, A. L. (2018). Online learning in higher education: Exploring advantages and disadvantages for engagement. Journal of Computing in Higher Education, 3O(3), 452-465. https://doi.org/10.1007/s12528-018-9179-z

Duncan, H. E., \& Barnett, J. (2009). Learning to teach online: What works for pre-service teachers. Journal of Educational Computing Research, 4O(3), 357-376. https://doi.org/10.2190/ec.40.3.f 
Ersin, P., Atay, D., \& Mede, E. (2020). Boosting preservice teachers' competence and online teaching readiness through E-practicum during the COVID-19 outbreak. International Journal of TESOL Studies, 2(2), 112-124. https://doi.org/10.46451/ijts.2020.09.09

Gold, S. (2001). A constructivist approach to online training for online teachers. Journal of Asynchronous Learning Networks, 5(1), 35-57. https://doi.org/10.24059/olj.v5i1.1886

Hudson, P., \& Nguyen, T. M. H. (2009). What do preservice EFL teachers expect from their mentors. In Jeffery, P. (Ed.) Changing climates: Education for sustainable futures: Proceedings of the Australian Association for Research in Education (AARE) International Education Research Conference 2008. Australian Association for Research in Education, Online, pp. 1-10.

Jaggars, S., \& Bailey, T. R. (2010). Effectiveness of fully online courses for college students: Response to a Department of Education meta-analysis. Columbia University Press.

Jung, I. S., \& Choi, S. H. (1999). A study on factors that affect the effectiveness of online open and distance training in a large corporate setting. Korea Journal of Educational Research, 37(1), 369-388.

Kabilan, M. K., Adlina, W. F. W., \& Embi, M. A. (2011). Online collaboration of English language teachers for meaningful professional development experiences. English Teaching: Practice and Critique, (10)4, 94-115.

Káplár-Kodácsy, K., \& Dorner, H. (2017). "I wish I had more time” Mentor teacher narratives of reflective practice: A case for online mentoring. In EDEN Conference Proceedings (No. 1, pp. 149-155).

Kırkgöz, Y. (2005). English language teaching in Turkey: Challenges for the $21^{\text {st }}$ century. In G. Braine (Ed.), Teaching English to the world: History, curriculum, and practice (pp. 159-175). Lawrence Erlbaum Associates.

Kırkgöz, Y. (2017). English education policy in Turkey. In R. Kirkpatrick (Ed.), English language education policy in the Middle East and North Africa (pp. 235-256). Springer. https://doi.org/10.1007/978-3319-46778-8_14

Nergis, A. (2011). Foreign language teacher education in Turkey: A historical overview. Procedia Social and Behavioral Sciences, 15, 181-185. https://doi.org/10.1016/j.sbspro.2011.03.070

Peel, K. L. (2020). A beginner's guide to applied educational research using thematic analysis. Practical Assessment, Research, and Evaluation, 25 (2), 1-15. https://doi.org/10.7275/ryr5-k983

Pena, C. M., \& Almaguer, I. (2007). Asking the right questions: Online mentoring of student teachers. International Journal of Instructional Media, 34(1), 105-113.

Poehner, M. E., \& Lantolf, J. P. (2005). Dynamic assessment in the language classroom. Language Teaching Research, 9(3), 233-265. https://doi.org/10.1191/1362168805lr166oa

Rodesiler, L., \& Pace, B. (2015). English teachers' online participation as professional development: A narrative study. English Education, 47(4), 347-378.

Rovai, A. P. (2003). In search of higher persistence rates in distance education online programs. The Internet and Higher Education, 6(1), 1-16. https://doi.org/10.1016/s1096-7516(02)00158-6

Saldaña, J. (2021). The coding manual for qualitative researchers. SAGE.

Seferoğlu, G. (2004). A study of alternative English teacher certification practices in Turkey. Journal of Education for Teaching, 3o(2), 151-159. https://doi.org/10.1080/0260747042000229762

Teräs, H. (2016). Collaborative online professional development for teachers in higher education. Professional Development in Education, 42(2), 258-275. https://doi.org/10.1080/19415257.2014.961094 
Wang, C., Pan, R., Wan, X., Tan, Y., Xu, L., Ho, C. S., \& Ho, R. C. (2020). Immediate psychological responses and associated factors during the initial stage of the 2019 coronavirus disease (COVID-19) epidemic among the general population in China. International Journal of Environmental Research and Public Health, 17(5), 17-29. https://doi.org/10.3390/ijerph17051729

YÖK: Mevlana Programı Temel bilgiler. (n.d.). Retrieved February 05, 2021 from https://mevlana.yok.gov.tr/belgeler

Zweig, J. S., \& Stafford, E. T. (2016). Training for online teachers to support student success: Themes from a survey administered to teachers in four online learning programs. Journal of Online Learning Research, 2(4), 399-418. reviewed journal that provides a forum for studies and dialogue about developments and change in the field of education and learning. The journal includes research and related content that examine current relevant educational issues and processes. The aim is to provide readers with knowledge and with strategies to use that knowledge in educational or learning environments. JERAP focuses on education at all levels and in any setting, and includes peer-reviewed research reports, commentaries, book reviews, interviews of prominent individuals, and reports about educational practice. The journal is sponsored by The Richard W. Riley College of Education and Leadership at Walden University, and publication in JERAP is always free to authors and readers. 